\title{
Evaluation the Incidence of Couvade Syndrome in Iranian Expectant Fathers
}

\author{
Arezoo Heydari ${ }^{1}$, Nourossadat kariman ${ }^{2}$, Farzaneh Ahmadi $^{3}$ \\ 1. MSc of Midwifery, Student Research Committee, School of Nursing and Midwifery, Shahid Beheshti University of \\ Medical Sciences, Tehran, Iran ORCID ID: 0000-0002-1881-741X \\ 2. Associate Professor, Midwifery and Reproductive Health Research Center, Midwifery and Reproductive Health \\ Department, School of Nursing and Midwifery, Shahid Beheshti University of Medical Sciences, Tehran, Iran. \\ (Corresponding Author), Tel: 02188202512, Email: n kariman@sbmu.ac.ir, . ORCID I D:0000-0001-8413-7175 \\ 3. Ph.D. student of Biostatistics, Department of Biostatistics, School of Para medicine, Shahid Beheshti University of \\ Medical Sciences, Tehran, Iran. ORCID ID: 0000-0001-5629-2001
}

\begin{abstract}
Background and Aim: Couvade syndrome is a syndrome that the father, like the mother, during pregnancy shows some of the changes and symptoms associated with pregnancy. The aim of this study was to estimate the rate of this syndrome in Iranian expectant fathers.

Materials and Methods: This descriptive cross-sectional study included 372 husbands whose wives were receiving prenatal care in the hospitals of Shahid Beheshti University of Medical Sciences in Tehran from January 2018 to December 2018. Using a researcher-made questionnaire the participants were evaluated for the signs and symptoms of couvade syndrome. All the women were in the third trimester of pregnancy.

Results: On average, every participant experienced $\% 3.12 \pm 3.61$ of the common symptoms of pregnancy during his wife's pregnancy. The most common symptoms in the fathers were stress and anxiety, decreased concentration, fatigue, sleep disorders, headache, and digestive problems such as increased appetite, heartburn, abdominal distension, and alterations in weight. In most cases, these problems occurred in the third trimester. Conclusion: In the present study, it has been shown that men also encounter certain changes and problems during the pregnancy of their wives. Therefore, it seems necessary to pay attention to the fathers and their needs in order to help them to prepare for parenthood.
\end{abstract}

Keywords: Couvade syndrome, Expectant fathers, Iran

Received: Dec 30, $2018 \quad$ Accepted: March 10, 2020

How to cite the article: Arezoo Heydari, Nourossadat kariman, Farzaneh Ahmadi. Evaluation the incidence of Couvade syndrome in Iranian expectant fathers. SJKU 2020;25(5):93-103.

Copyright (C) 2018 the Author (s). Published by Kurdistan University of Medical Sciences. This is an open access article distributed under the terms of the Creative Commons Attribution-Non Commercial License 4.0 (CCBYNC), where it is permissible to download, share, remix, transform, and buildup the work provided it is properly cited. The work cannot be used commercially without permission from the journal 


\section{بررسى ميزان بروز سندرم كويد در بدران در انتظار فرزند ايرانى}

آرزو حيدرى'، نورالسادات كريمان"، فرزانه احمدى"

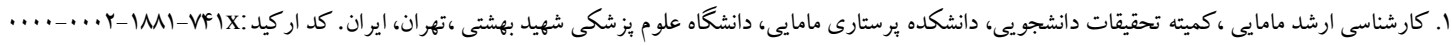

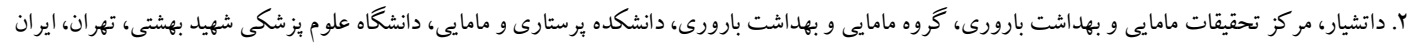

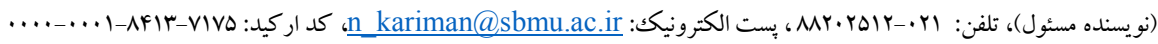

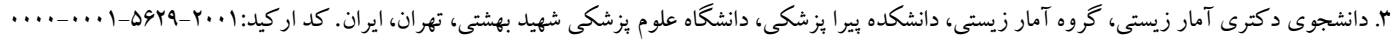

جـكيده زمينه و هدف: سندرم كويد، سندرمى است كه طى آن بدر نيز همانند مادر در طول باردارى برخى از تغييرات و علائمم مربوط

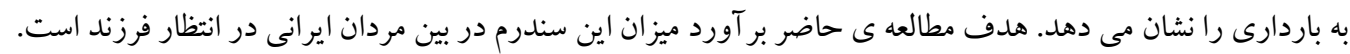

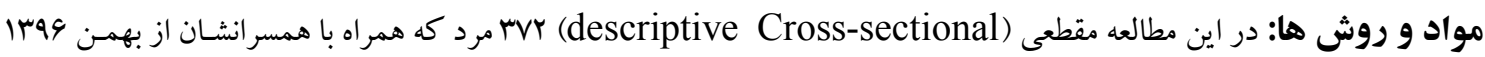

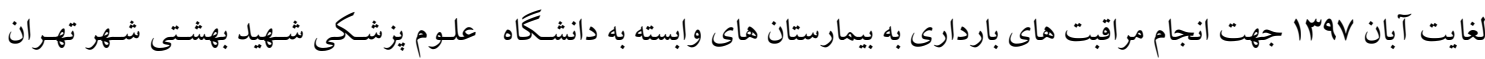

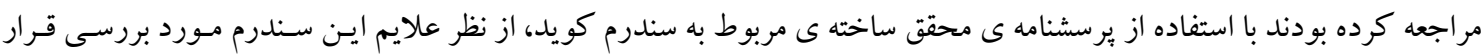

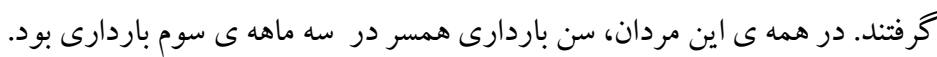

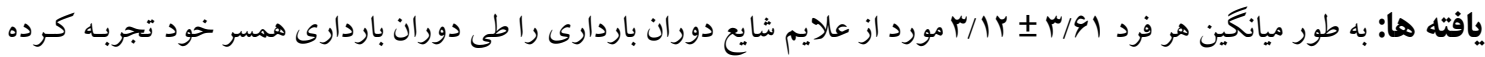

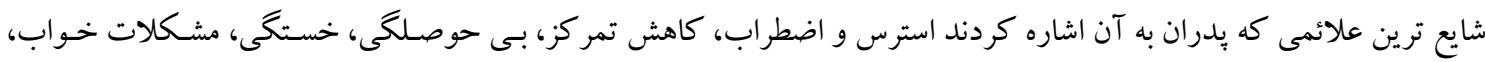

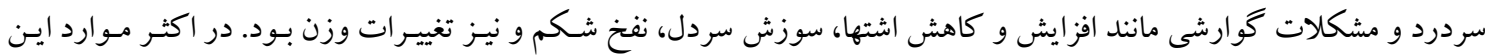
مشكلات در سه ماهل سى سوم اتفاق افتاده بود. نتيجه كيرى: در مطالعه ى حاضر نشان داده شد كه مردان نيز در طول باردارى همسر خوده، با تغييرات و مشكلات خاصى مو اجـه

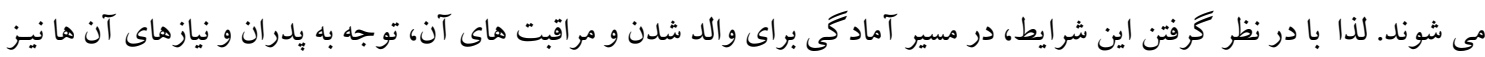
الز امى به نظر مى رسد. كلمات كليدى: سندرم كويد، بِدران در انتظار فرزند، ايران

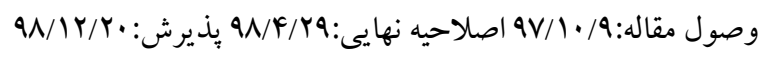


مستعد اضطراب و استرس هستند، بيشتر است. امروزه يــدران به علت آكَاهى بيشتر نسـبت بـه نقـش بـدرى و دوران تولـد

فرزند بيشتر در معرض خطر سندرم كويد هستند( (1).

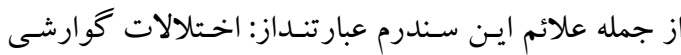
مانتـد تهـوع، اسـتفراغ، سـوزش سـردل، تغيير اشـتها، علايـم روانى، اختلالات خواب، افسـردگى، كـاهش ميـل جنسى، كمردرد، گرفتگى و ضعف عضلات با و مشكلات ادرارى تناسلى ( •1). بيشترين علائمى كه مـردان از خـود نشـان مـى دهند مربوط بـه اخـتلالات گو ارشى اسـت و علايـم روانى شيوع كمترى دارند( (1). زمان شروع اين علائسم متناسـب و همز مان با مرحلـه ى بـاردارى اسـتـ( • (). علائسم ذكـر شـده بيشتر در سه ماهه ى اول و سوم رخ داده(Y) I و ممكن اسـت موقتا در سه ماهه ى دوم علامتى وجود نداشته باشد( •() اين

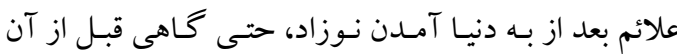
متوقف مى شوند و امكان عود در بـاردارى هـاى بعـدى نيز

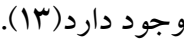

تا كنون ارتباط واضحى بين فاكتورهاى اجتماعى و جمعيـت

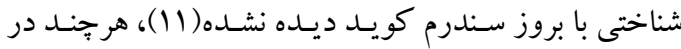
برخى مطالعات ديده شده كـه در جوامـع صـنعتى بيشتر رخ

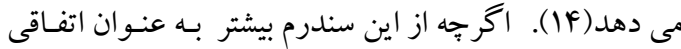
طبيعى و مرتبط با بادارى ياد مى شود، اما بايد توجـه داشـت كه سلامت يدران، به عنوان مسئول خانواده، و نيز ساز گارى آن ها با نقـش يــدرى و درسـت ايفـا كـردن ايـن مسـوليت ارتبـاط نزديكى بـا سـلامت مـادر و سـاير اعضـاى خـانو اده دارد(ه) (1). حـال آن كـهـ در ايسن دوران تمـام توجهـات بـه سمت مادر مى باشــــ او در طـول دوران بـاردارى و توسط اعضاى مختلف تسيم ارائسه دهنـده ى مراقبـت هـاى بـاردارى . مورد ارزيابى هاى جـامع و مختلفى قرار مسى كيرنـد، امـا

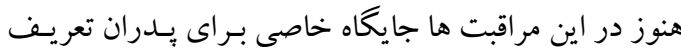
نشده است. در اين بين ماماها و ارائهـ دهنـدكان مراقبـت بـهـ خانم هاى باردار به عنوان كسانى كه بيشـترين برخـورد را بـا زوجين باردار دارند ممكـن اسـت بـا جنـين مـواردى مواجـهـ شوند. بنابراين لازم است كه علاوه بر مادران، به نقش بدرها
مقدمه

امروزه حضور و دخالت يدرها در دوران بـاردارى و زايمـان

براى كمكك و حمايت از همسر الزامى به نظر مى رسـد(1).

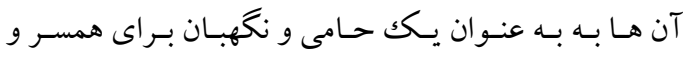
فرزندان خود هستند و در ارتقاى سـلامتى خـانواده از نقـش مهمى برخوردارند(Y). باردارى و والد شدن از اتفاقات مهـم

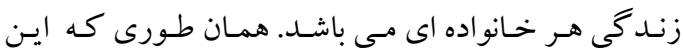
دوران براى مادر از اهميت ويـزّه اى برخـوردار اسـت، يـدر نيز در اين دوران نخر انى ها و اضطر اب هاى خـاص خـود را دارد. او هم بايد محافظ همسر و فرزندش باشد و هـم عهـده دار مسئوليت زندگى(T) اما امروزه بيشتر توجهات به سـمت مادر است و به يدر و تغييرات روحى او توجـه زيـادى نمى شـود(F). ايسن درحسالى اسـت كـه يـــران در انتظـار فرزنـــ نيزهمانند مادران، نياز به حمايت هاى خاص خود دارنـد(ه). در مطالعات ديله شده كه توجـه بـه نقـش بــدرى در دوران بـاردارى ارتبـاط مسـتقيمى بــا رابطـه ى بـين فرزنـــ و يــدر دارد(9). همجينين ديده شده هر جقدر نقش بـدرها در دوران باردارى و بعد از آن بيشتر باشد، رشد و تكامل كودكك بهتر مى شود. اين تاثير از طريق بهبود وزن كيرى كـودك، بهتر

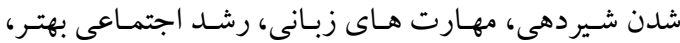
سطح بالاتر اعتماد به نفس و تحصيلات فرزندان حاصل مى شـود(V). از طرفى دخالـت دادن يـــرها در امـر بـاردارى و افزايش آكَاهى آن ها موجب عكس العمل هاى متفاوتى در آن ها مى شود، جون آن ها در ايسن بروسـه فقط نظـاره كَر

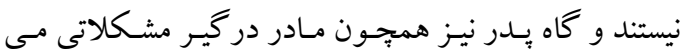
شود. يكى از مشكلاتى كه ممكن است بـراى بـدران درايسن دوران ايجاد شود، سندرم كويـــ اسـت (1) در ايـن سـندرم

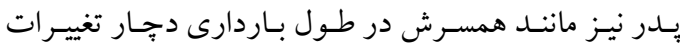
مربوط به باردارى مى شود(^). طى مطالعهى جامعى كه توسط Brennan انجـام شـد،

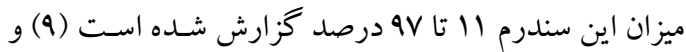
ميز ان آن در بين مردانى كـه از نظر عـاطفى حسـاس انـد و

\footnotetext{
${ }^{1}$ Couvade syndrom
}

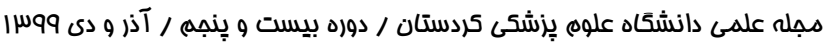


94

استراحت هاى طـولانى و نيـز سـابقه بـ بـترى در بـاردارى

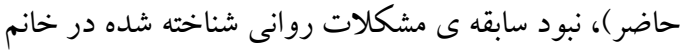
و همسـرش، نبود سـابقه مشـكل طبى خـاص و مخـاطره

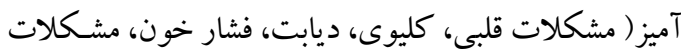

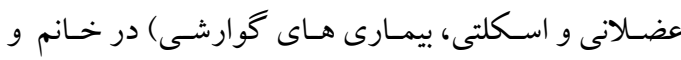
همسرش، سن بارادارى YA-FY هفته كامل، بدر بيولوزيكك بودن، متاهل بودن و هم خانه بـودن زوجين، عـدم رخخ دادن حادثه استرس زا (از ابتداى باردارى كنونى) براى هريك لهُ

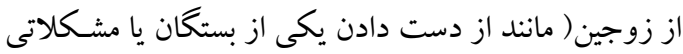

$$
\text { مانند از دست دادن شغل و...). }
$$

بر سشنامه هاى مورد استفاده در اين مطالعه شامل؛ برسشـنامه هاى اطلاعات دمو گر افيك و وبرسشنامه ى محقق ساخته ى سندرم كويد بود. اين برسشنامه با استفاده از مطالعات مرتبط

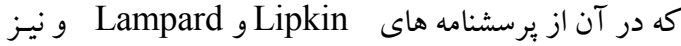
يرسشـناهه ى Brennan كـه هـر دو بـراى ارزيابى سـندرم كويد هستند، طراحى شــ(1, rا, و در مجمـوع افراد را از نظر M شكايت شايع دوران باردارى مورد ير سش قرار مى هى داد. بِ از طراحى نهايى برسشنامه، توسط • إنفر از اساتيد متخصص مامـايى، بهداشـت بـارورى، زنـان، روانشناسى و

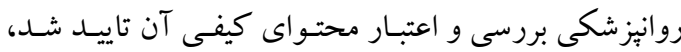
همجنين اين برسشنامه ها توسط ها نفر از مراجعين به مراكز منتخب تكميل و روايى صورى آن نيز بررسى و تاييـد شـد. بإيـايى ابززار بـه روش آزمهون-بـاز آزمون مـورد تاييـد قرار

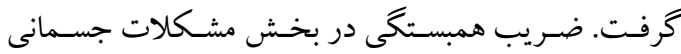

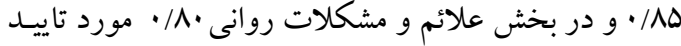

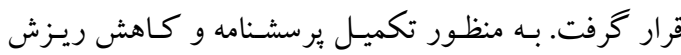

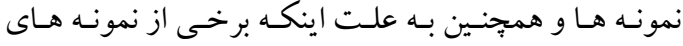
شر كت كننده در مطالعه فاقد سواد خو اندن و نوشتن بودنـد، سوالات برسشنامه ها توسط فرد همكار ثيزوهش براى بدران

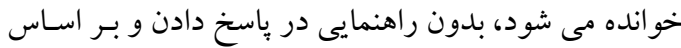

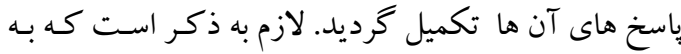

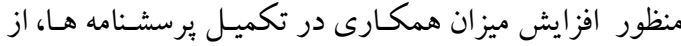
يرسشخر مرد در تكميل برسشنامه هاى مردان استفاده شد.
نيـز در دوران بـاردارى و زايمـان توجـه شـود. يكسى از راه

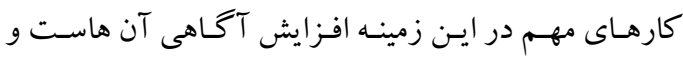
شركت در كلاس هاى دوران باردارى ممكن است در ايـن مورد كمكك كننده باشد (1). مطالعه ى حاضر باهدف تعيين ميزان سـندرم كويـد دربين همسر ان خانم هاى باردار مراجعـه كنتـده بـه درمانكـاه هـاى لهاى

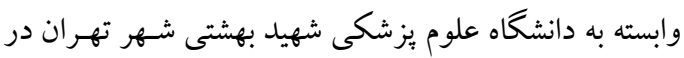

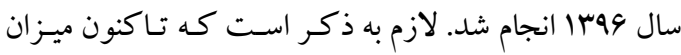

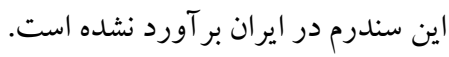

مواد و روش ها مطالعه ى حاضر يكك مطالعه ى مقطعى-توصيفى است كه.

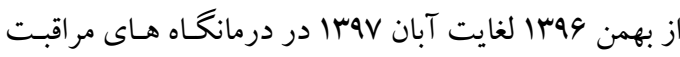

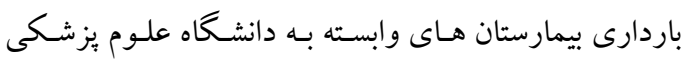

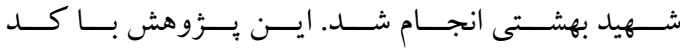

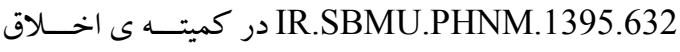
دانشگاه علوم يزشكى شهيد بهشتى ثبت شده است. در ايـن مطالعه rVT مرد در انتظار فرزند كه همراه بـا همسران خهود

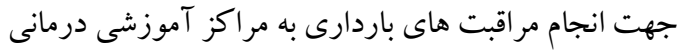

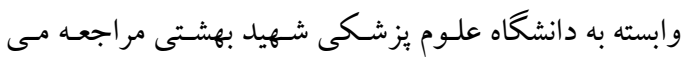
كردند از نظر علايم سندرم كويد مورد بررسى قرار گر فيتند.

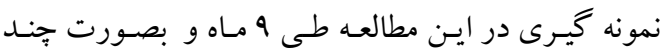

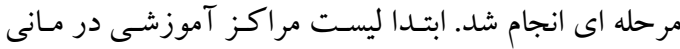

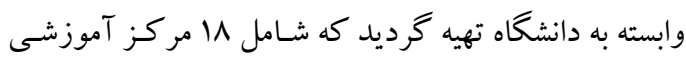

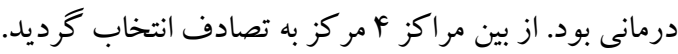
به هر مركز بر اساس تعداد زنان باردار مراجعه كننده سهميه

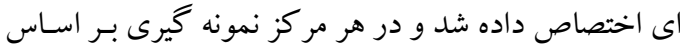
معيارهـاى ورود بـهـ مطالــه و بـهـ روش در دسـترس انجـام

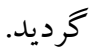
معيارهاى ورود به مطالعه شـامل مـوارد زيـر بـود: كمى خطر بودن باردارى فعلى( نداشتن سابقه مواردى مانند فشار خـون

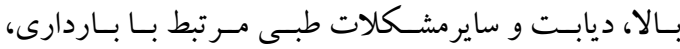
ناهنجارى تشخيص داده شـده در جنـين، مشكلات نيازمنـد 
9V نورالسادات كريمان

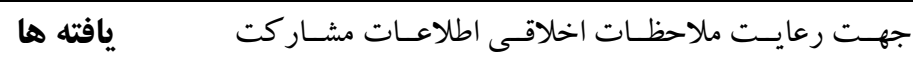

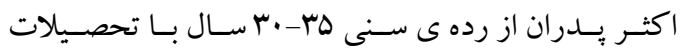

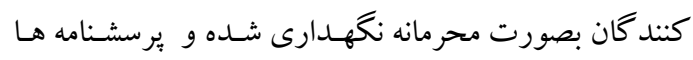

دبيرستان و شغل آزاد بودند، در بيش از نيمى از اين افراد نيز

بدون اسم ثبت مى شد. در صـورت عـدم تمايسل مشـاركت

سن باردارى همسر MV-FY هفته بود. از نظر ديسن و مـذهب؛

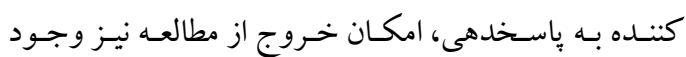
همه ى اين بِدران مسلمان و •9 درصـد آن هـا شـيعه بودنـد، نتايج مربوط به اطلاعـات دمو گر افيكك يـدران در جـدول داشت. يُس از اتمام فر آيند نمونه گيرى، داده هـا بـا اسـتفاده

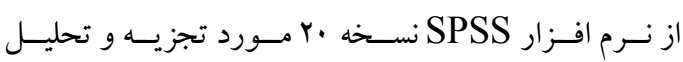
ارائه شده است.

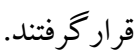

جدول شماره ا. مشخصات دمو كر افيك يدران شر كت كننده در مطالعه

\begin{tabular}{|c|c|c|c|}
\hline درصد & فراوانى & طبقه & متغير \\
\hline$r e / T^{c}$ & 91 & $r+-r q / q$ & \multirow{4}{*}{ سن (سال) } \\
\hline$m e / V$ & 149 & $r+-r f / q$ & \\
\hline$r \Delta / \Delta$ & $9 \Delta$ & $r \Delta-r q / q$ & \\
\hline $1 r / \kappa$ & Q. & بالاى + f & \\
\hline 1.10 & rq & كمتر يا مساوى rس & \multirow{3}{*}{ سن باردارى(هفته) } \\
\hline 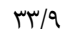 & 每 & rw-rv & \\
\hline$\Delta \omega / \bar{\varepsilon}$ & $r \cdot V$ & بيشتر يا مساوى ^ץ & \\
\hline$r / \kappa$ & 19 & بى سواد & \multirow{5}{*}{ تحصيلات } \\
\hline $\mid r / 9$ & iv & ابتدايى & \\
\hline$r+\cdot$ & NT & راهنمايى & \\
\hline$r V / f$ & 179 & دبيرستان & \\
\hline$r \mu / V$ & $\Lambda$ & دانشخاهى & \\
\hline$\cdot / \mu$ & 1 & بيكار & \multirow{5}{*}{ 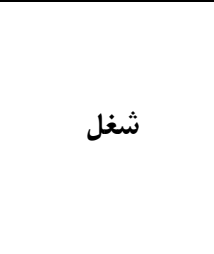 } \\
\hline $19 / 9$ & $v^{4}$ & كارتر & \\
\hline $1 \% / \Lambda$ & $\Delta \Delta$ & كارمند & \\
\hline$\varepsilon r / V$ & rTr & شغل آزاد & \\
\hline $1 / r$ & Q & ساير مشاغل & \\
\hline
\end{tabular}

نوسانات خلقى و سردرد بودند، همجينين در درجه ى بعلى يدران از مشكلات كوارشى از قبيل كاهش و يا افزايش اشتها، نفخ شكم و سوزش سر دل شاكى بودند. نفر (19/4 \%) از پيدران به افزايش وزن و سه نفر (1/9 \%) نيز به كاهش وزن در طول دوران باردارى همسر خود اشاره كردند. ساير نتايج مربوطه در جدول ب ارائه شده است.
به طور ميانگين هر يكك از يدران تعداد علائم · و حداكثر تعداد علائم 11) مورد از علايم شايع دوران باردارى را طى دوران باردارى همسر خود تجربه كرده بودند و از اين بين بيشترين مشكلاتى كه بدران در طول باردارى همسر خود ذكر كردند مواردى مانند، استرس و اضطراب در مورد سلامت همسر و جنين او، كاهش تمركز، بى حوصلكَ، خستكى، مشكلات خواب، 
جدول ז. علائم و مشكلات يدران شر كت كننده در مطالعه در طول باردارى همسر و زمان بروز اين مشكلات

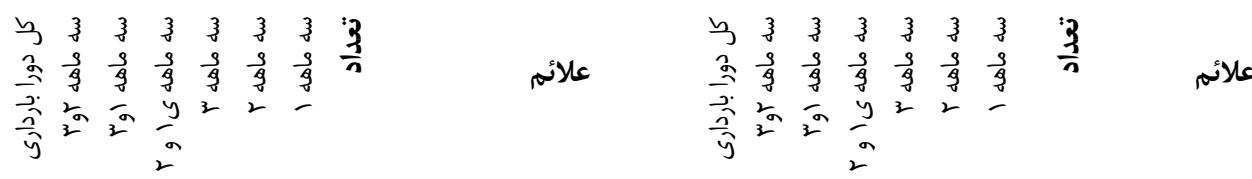

\begin{tabular}{|c|c|c|c|c|c|c|c|c|c|c|c|c|c|c|c|c|c|}
\hline - & 1 & - & . & r & 1 & & $(1 / \Gamma) \Delta$ & خون ريزى ازبينى & $\cdot$ & 1 & 1 & - & 1. & $\Delta$ & 11 & $(V / \Delta) Y \Lambda$ & تهوع \\
\hline - & 1 & • & . & f & 1 & 1 & $(1 / 9) V$ & لكه هاى يوستى & . & 1 & . & - & 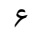 & f & 8 & $(F / 8) I V$ & استفراغ \\
\hline r & 1 & • & • & $\wedge$ & f & r & $(\xi / \varepsilon) \backslash V$ & خارش يوست & r & r & • & 1 & ir & 1. & 8 & $(9 / 1) m F$ & نفخ شكم \\
\hline 1. & f & $\cdot$ & 1 & va & f & . & $(r \xi / r) q \Lambda$ & كاهش تمر كز & r & r & • & • & $\varepsilon$ & $\checkmark$ & r & (D/Q)RT & يبوست \\
\hline v & • & r & 1 & r. & r & . & r/s) & كابوس هاى شبانه & r & - & · & • & $\Delta$ & f & . & $(r / \cdot) M$ & اسهرال \\
\hline$r$ & • & • & - & • & r & - & $(1 / 1)^{r}$ & ترس از تنهايى & 9 & 9 & 1 & • & $M$ & $\wedge$ & r & $\begin{array}{c}r+8) \\
(11 / 8)\end{array}$ & سوزش سر د \\
\hline 1. & f & • & r & Vq & r & r & $(r \varepsilon / 1) q v$ & بى حوصلكى & $\Delta$ & 10 & • & 1 & IV & f & 1 & 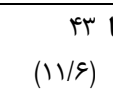 & افزايش اشته \\
\hline 9 & r & • & 1 & 81 & Q & r & $\begin{array}{c}M \\
(T r / V)\end{array}$ & خستكى & 9 & 1. & - & • & r) & $\checkmark$ & r & $\begin{array}{c}\Delta \cdot \\
(\mid r / F)\end{array}$ & كاهش اشته \\
\hline$\Delta$ & f & $\cdot$ & 1 & fe & & f & $\begin{array}{c}G Y \\
(I \& / V)\end{array}$ & نوسانات خلقى & . & r & . & 1 & سו & $r$ & 1 & $(\Delta / \varepsilon) Y I$ & دل درد \\
\hline צ & 1 & $\curlywedge$ & r & 91 & r & if & $\begin{array}{l}1 D Q \\
(F) / V)\end{array}$ & استرس واضطر اب & 1 & $\Delta$ & • & - & r & 9 & r & $(V / r) T V$ & دندان درد \\
\hline$\Delta$ & r & 1 & 1 & is & r & f & $\begin{array}{c}91 \\
(19 / 4)\end{array}$ & مشكلات خواب & 9 & $\Delta$ & - & • & ra & f & 1 & $\begin{array}{r}\Delta 1 \\
(1 T / V)\end{array}$ & سردرد \\
\hline$\Delta$ & $\cdot$ & $\cdot$ & 1 & 1. & 1 & r & $(\Delta / 1) 19$ & احساس بى ارزشى & r & r & • & • & 19 & r & $\cdot$ & (V/•) re & كمر درد \\
\hline 8 & r & • & • & r & זו & 1 & $\begin{array}{c}\Delta F \\
(\mid F / D)\end{array}$ & افزايش وزن & r & r & · & • & $r$. & 9 & 1 & 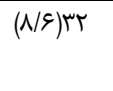 & يا درد \\
\hline - & r & • & 1 & $1 f$ & f & . & $(\Delta / 9) K r$ & كاهش وزن & v & r & . & • & 19 & 1 & r & (N/q) & ضعف و بى \\
\hline
\end{tabular}

جدول ז. علائم و مشكلات يدران شر كت كننده در مطالعه در طول باردارى همسر و زمان بروز اين مشكلات

\begin{tabular}{|c|c|c|c|c|c|c|c|c|}
\hline كل دوران & سه ماهد & سه ماهد & سه ماهد & سه ماهd & سه ماهd & سه ماهd & تعداد & علائم \\
\hline$\cdot$ & $r$ & 1 & $\cdot$ & 19 & 9 & IV & $(I T / I) F \Delta$ & تهتوع و استفراغ \\
\hline r & $r$ & • & 1 & ir & 1. & 8 & $(q / 1) m e$ & نفخ شكم \\
\hline$\Delta$ & r & • & • & 11 & 11 & $r$ & 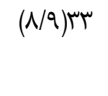 & يبوست و اسهال \\
\hline
\end{tabular}


نورالسادات كريمان

\begin{tabular}{|c|c|c|c|c|c|c|c|c|}
\hline 8 & 8 & 1 & • & $M$ & $\wedge$ & r & שז (11/9) & سوزش سر \\
\hline If & TA & · & 1 & щ & 11 & r & (ro)qr & تغيير اشتها \\
\hline • & r & • & 1 & זו & r & 1 & $(\Delta / \mathcal{G})$ rI & دل درد \\
\hline 1 & $\Delta$ & · & $\cdot$ & r & 9 & r & $(V / r) T V$ & دندان درد \\
\hline$\varepsilon$ & $\Delta$ & . & · & ra & $f$ & 1 & $(I r / V) \Delta I$ & سردرد \\
\hline$\Delta$ & $\Delta$ & · & • & एव & $\wedge$ & 1 & 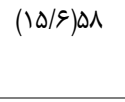 & كمر درد - \\
\hline v & $r$ & • & $\cdot$ & 19 & 1 & $r$ & سו & ضعف و بى \\
\hline • & 1 & • & $\cdot$ & r & 1 & · & $(1 / \Gamma) \Delta$ & خون ريزى ازبينى \\
\hline r & r & · & $\cdot$ & ir & $\Delta$ & $r$ & $(\varepsilon / Q) r F$ & مشكل \\
\hline 1. & f & • & 1 & va & f & • & $(r \varepsilon / \Gamma) q \Lambda$ & كاهش كن \\
\hline 9 & . & r & 1 & r. & r & . & ع צ'(q/V) & تربان \\
\hline 19 & $v$ & • & r & life & $\wedge$ & r & $(\mp q / \wedge) \backslash \wedge \Delta$ & خوصلَّى - حستَى \\
\hline$\Delta$ & r & . & 1 & fe & f & r & $(1 \& / V) \& T$ & نوسانات \\
\hline צ & 1 & 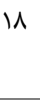 & r & 91 & r & $1 f$ & $\begin{array}{l}1 Q D \\
(f) / V)\end{array}$ & واضطراب \\
\hline Q & r & 1 & 1 & is & r & r & $(18 / 5) \& 1$ & خشكلات \\
\hline$\Delta$ & $\cdot$ & • & 1 & 1. & 1 & r & $(\Delta / 1) 19$ & بى ارساس \\
\hline 8 & $\varepsilon$ & - & 1 & Ed & IV & 1 & $(r \cdot / F) V \varepsilon$ & تغير وزن \\
\hline
\end{tabular}

علائم برابر با |/س درصد و شيوع دو علائم \$ \$ درصد بود در مجموع يـدران بوال مـورد از علائسم و مشككلات ذكر و م/ه" درصد از يــدران نيـز حـداقل سـه مـورد از علائسم را شده در برسشنامه رادر طـول دوران بـاردارى همسر خـود تجربه كرده بودنـــا.يـن علائسم بـه تفكيكك سـه ماهـه هـاى تجربه كرده بودند كه همان طور كه در جـدول نشـان داده مختلف و كل دوران باردارى در جدول شماره ب ارائه شـده شــده، در اكثـر مـوارد علائسم ذكـر شـده در سـه ماهـه سـوم است. همانطور كه در جدول ب مشخص شده است اكثر اين

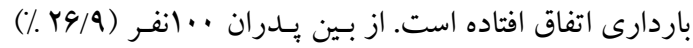

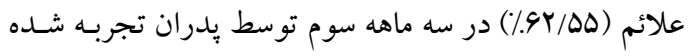
هيج كدام از علائم را تجربه نكرده بودند، هY نفر (9/VY.) است. از كليه علائسم و نشـانگًان تجربـه شـده توسط يـدران داراى حداقل · ا علائم بودند. شـيوع حسداقل يكى از ايـن

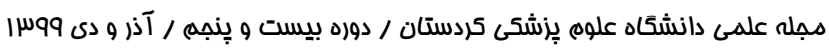


100 براسى ميزان بروز...

نفر ) از موارد نيـز از بصـورت خيلـى شـديد گَزارش شـدده

بودند.

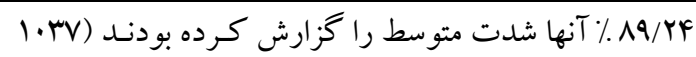

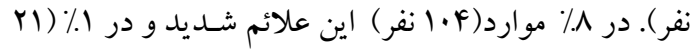

جدول r. زمان بروز علائم تجربه شده توسط يدران شركت كننده در مطالعه

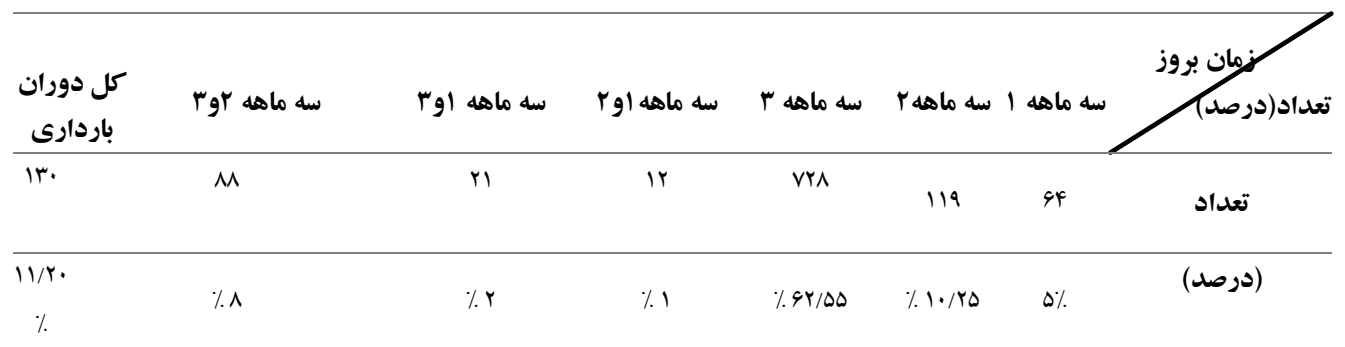

است. از ساير علائمى كه در اين سندرم ديده مسى شـود مسى

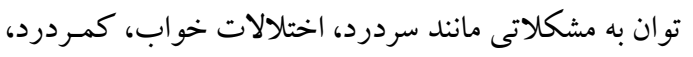

ضعف عضلات يا و دل درد اشاره كرد(·).

در ايران تا به حـال مطالعـه اي بـا ايسن عنـوان انجـام نشــدهو اطلاعاتى در مورد ميزان بروز ايسن سـندرم در مـردان ايرانى وجود ندارد و تنها مطالعه ى انجـام شـده توسط ضـرابى و خلخـالى در سـال •^شا مسى باشـد كـه در آن يـك مـورد سندرم كويد با تظاهرات افسردگى كه در يى بسترى كردن همسر جهت زايمان ايجاد شده بود، گزارش گرديد(IV) لذا مطالعه ى حاضر اولين مطالعه ایى است كه بـه بررسى ميـزان

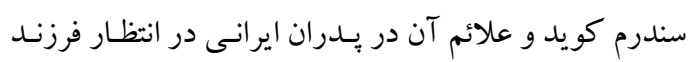
يرداخته است.

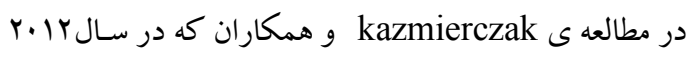
در لهستان انجام شد، مشاهده كردند كه VY درصد از يـدران حداقل يكى از علائسم رادر دوران بـاردارى همسـر تجربـه

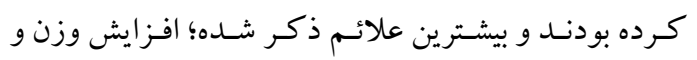

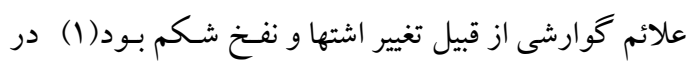
مطالعه ى Ganaphathy كـه در سـال F ا •r در هنـد انجـام شد بيشترين موارد گزارش شده شامل مشكلات گوارشى از قبيل نفخ شـكم، تغييـر اشـتها، يبوسـت، سـوء هاضـمه و نيـز مشكلاتى از قبيل خستخى، بى خوابى، تغييرات خلق و خـو

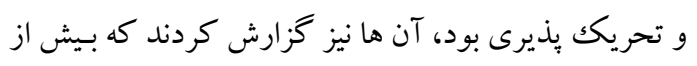
99 در صد مردان حداقل يـك مـورد از شـكايت هـاى شـايع
در اين مطالعه نشان داده شد كه تا مرحله اى از باردارى كه

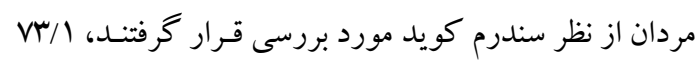
درصـد از آن هـا حـداقل يـكك مـورد از علائسم شـايع دوران باردارى را تجربه كرده بودند و تنها 9/9 درصد از مـردان دوران باردارى همسر را تا اين مرحله بدون تجربه ى مشكل خاصى سبرى كرده بودند. اين ميز ان، نسبت به مطالعاتى كـه

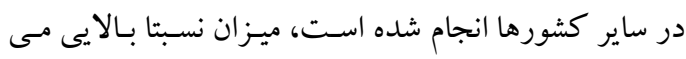
باشـــ. بـه عنـوان مثـال در بررسـى مـــدان اسـتر اليايى، ميـزان سندرم كويد حدود اس درصد، در مردان آمريكايى بr-هان درصد و در مردان سوئدى حدود · r درصـد گززارش شـده است. در برخـى ديخــ از مطالعـات ميـزان بيشـترى از ايسن

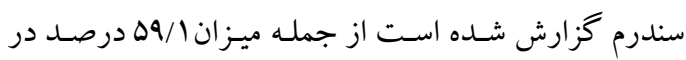
مردان اردنى و VY درصد در مردان لهستانى (19). همان طور كه گفته شد، دوران باردارى و بدر شدن يكى از مهم ترين اتفاقات زندگى است و سندرم كويد نيـز يكى از

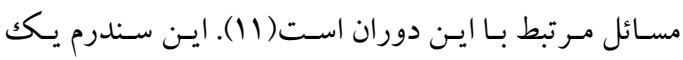
بيمارى نيست، بلكه واكنشى طبيعى نسبت به باردارى همسـر است(9) و امـروزه بـه علـت مشـاركت بيشـتر مـردان در امـر باردارى همسر و به دنبال آن افزايش آخحاهى آن هـا در ايسن زمينه، احتمال سـندرم كويـــ نيـز در آن هـا بيشـتر اسـت( (1). شايعترين علائمى كه مردان در ايسن سـندرم ذكـر مسى كنــد

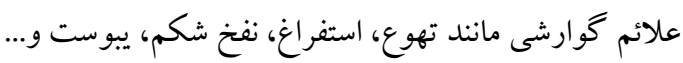


سه ماهه ى اول و سوم رخ داده(Y) (I و ممكن است موقتا در

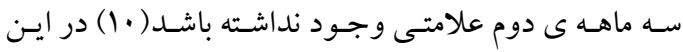

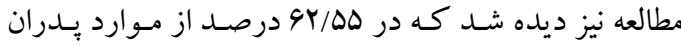

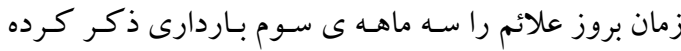
بودند اما بر خلاف آن كه انتظار مى رود در سه ماهـه ى اول ميزان علائم بيش از سـه ماهـه ى دوم باشــ، در ايـن مطالعهـ فر اد به نسبت سه ماهه ى اول باردارى، علائم بيشترى رادر سه ماهه ى دوم ذكر كرده بودند. هرجند با توجه به نتايجى كه در مورد شدت اين علائم ذكر شده است، مى توان جنين برداشت كرد كه اين ايسن سـندرم و تغييرات آن شايد براى مـردان مشكلات قابـل توجهى را ايجاد نكند اما با توجه به اهميت حضـور و مشـار كت بــدران در دوران باردارى و زايمان همسـر و نيـز بعـد از آن، ممكـن است ماماها و گُروه ارائه دهنده ى خدمت به مـادران بـاردار

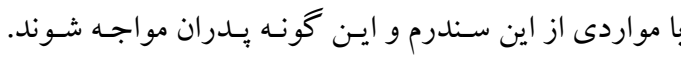
يدران نقش مهمى را در ارتقاى سـلامت خـانو اده ى خـود دارند و سلامت آن ها خصوصا بعد روانى آن و نيز انطابق آنان ها با نقش يـدرى و درسـت ايفـا كردن ايـن مسـؤوليت

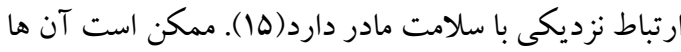

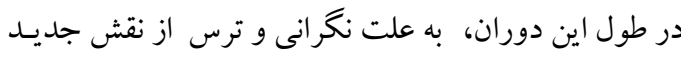
خود احساسات مختلفى را تجربه كند(11) كاهى بدران در اين روند نياز به حمايت اساسى دارند، بنابر اين به عنوان يك نياز الزامى به نظر مى رسد كه در امر باردارى علاوه بر مادر،

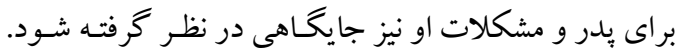
يكى از راه كار هاى بيشنهادى در اين مورد افزايش آكاهى براه

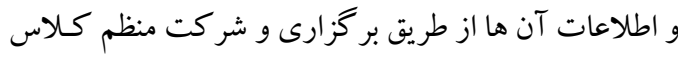
هاى دوران باردارى با حضور يدراست(1). از نقاط قوت ايـن طرح مسى توان بـه جديــ بـودن عنوان

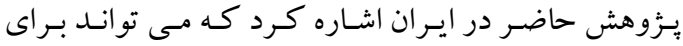

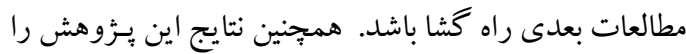
مى توان بـراى برنامـه ريزى و بهببود كيفيـت مراقبـت هـاى

$$
\text { دوران باردارى استفاده كرد. }
$$

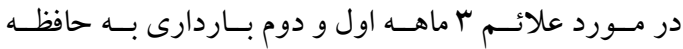
مشار كت كنند كان تكيه شد كه در باره ایى از مو اقع ممككن
دوران باردارى راذ ذكر كرده بودند كه حدود الr درصد آن

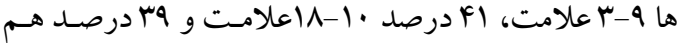
بيش از 19 مـورد از علائم را تجربـه كرده بودنــ(11). در

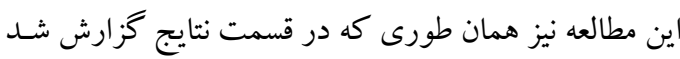

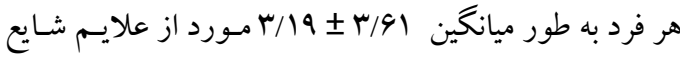
دوران بـاردارى راطى دوران بـاردارى همسـر خـود تجربـه كـرده بودنـــ. بـر خـلاف دو مطالعه ى ذكـر شــده علائسم روانشناختى از قبيل استرس و اضطراب، كاهش تمر كز، بـى بـ بـ

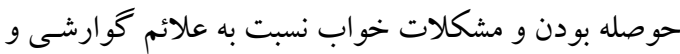

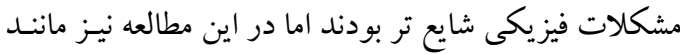

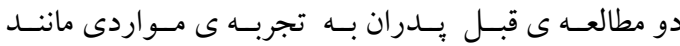

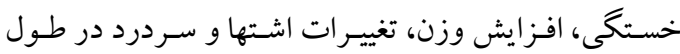
دوران باردارى همسر خود اشاره كرده بودند.

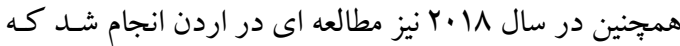
بـيش از سـاير مطالعـات از نظر روش تحقيق بـه مطالعـه ى

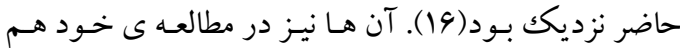
ميزان علائم و هم شدت آن ها را بررسى كردنـد. در نتيجهـ

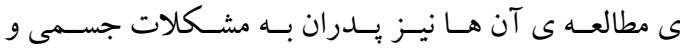
روانشناختى متعلدىى اشاره كرده بودنــ كه بـا وجود شـايع بودن مشكلاتى مانند استرس و نكر انس، مشككلات خـواب،

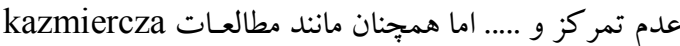
Ganaphathy در مـــدان اردنسى نيـز ميـزان مشـكلات جسمى، از جمله مشكلات كو ارشى بيشـرى تجربـه شـده Kazmierczak مردان مختلف بيان مى كند كه شـايد مردانى كـه بيشتر در ويزيت هاى دوران باردارى شركت دارند، به علائم بيشترى از اين سندرم اشاره كنند(1) و Lina نيز در ايـن مـورد بيـان مى كند كه در برخى مناطق به علت عـدم آكاهى مـردم از

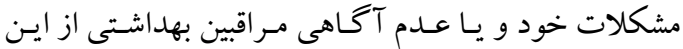
مشكلات، ممكن است مشكلات ذكر شده به ميزان كمترى

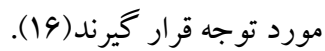

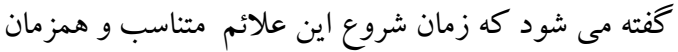

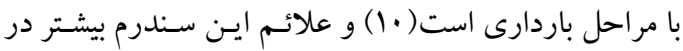

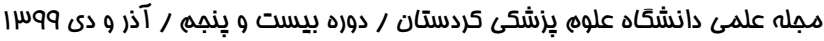




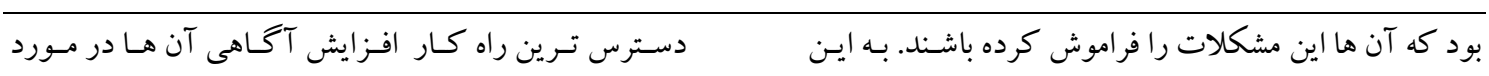

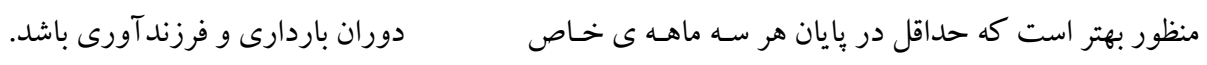

$$
\begin{aligned}
& \text { باردارى در مورد همان دوره سوال يرسيده مى شد. يا اينكه. } \\
& \text { تقدير و تشكر } \\
& \text { مقاله ى حاضـر حاصل از طـرح تحقيقـاتى مصسوب مركز } \\
& \text { در بزوهش هاى بعدى بيشنهاد مى شود جمعيت هـاى مـورد } \\
& \text { بررسى در سه ماه هاى مختلف باردارى قرار داشته باشند. } \\
& \text { تحقيقات مامايى و بهداشت بارورى، دانشـكده ي برستارى }
\end{aligned}
$$

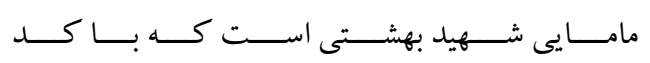

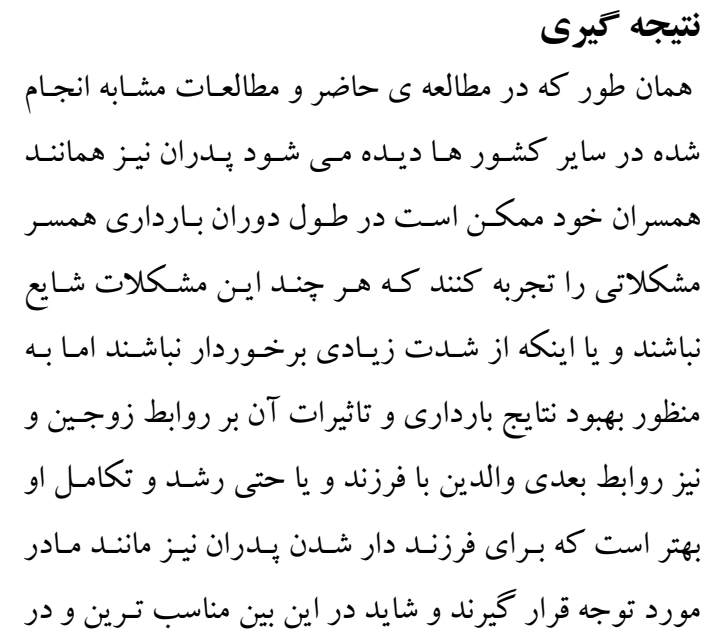

$$
\begin{aligned}
& \text { IR.SBMU.PHNM.1395.632 در كميتـه ى اخـلاق }
\end{aligned}
$$

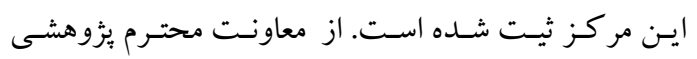

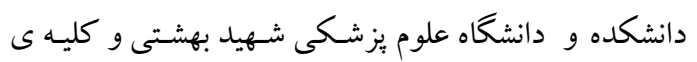

$$
\begin{aligned}
& \text { مشار كت كنند گان محترم، مسئولين و همكار ان بيمارسـتان } \\
& \text { هاى وابسته بـه دانشـكاه علوم بزشـكى شهيد بهشتى و نيـز } \\
& \text { ساير كسانى كه ما را در انجام اين بثزوهش همراهـى كردنـد، } \\
& \text { تشكر و قدردانى مى شود. }
\end{aligned}
$$

1. Kazmierczak M, Kielbratowska B, Pastwa-Wojciechowska B. Couvade syndrome among Polish expectant fathers. Medical science monitor : international medical journal of experimental and clinical research. 2013;19:132-8.

2.Sarkadi A, Kristiansson R, Oberklaid F, Bremberg S. Fathers' involvement and children's developmental outcomes: a systematic review of longitudinal studies. Acta paediatrica. 2008;97(2):153-8.

3. Bartlett EE. The effects of fatherhood on the health of men: a review of the literature. Journal of Men's Health and Gender. 2004;1(2-3):159-69.

4. Fägerskiöld A. A change in life as experienced by first-time fathers. Scandinavian journal of caring sciences. 2008;22(1):64-71.

5. Finnbogadóttir H, Svalenius EC, Persson EK. Expectant first-time fathers' experiences of pregnancy. Midwifery. 2003;19(2):96-105.

6 . Habib C, Lancaster S. The transition to fatherhood: Identity and bonding in early pregnancy. FATHERING-HARRIMAN-. 2006;4(3):235.

7. Garfield CF, Isacco A. Fathers and the well-child visit. Pediatrics-English Edition. 2006;117(4):e637.

8. Klein H. Couvade syndrome: male counterpart to pregnancy. The International Journal of Psychiatry in Medicine. 1991;21(1):57-69.

9. Brennan A, Ayers S, Ahmed H, Marshall-Lucette S. A critical review of the Couvade syndrome: the pregnant male. Journal of Reproductive and Infant Psychology. 2007;25(3):173-89.

10. Schodt CM. Parental-fetal attachment and couvade: a study of patterns of human-environment integrality. Nursing science quarterly. 1989;2(2):88-97.

11.Ganapathy T. Couvade syndrome among 1 st time expectant fathers. Muller Journal of Medical Sciences and Research. 2014;5(1):43. 
نورالسادات كريمان

12. Brennan A, Marshall-Lucette S, Ayers S, Ahmed H. A qualitative exploration of the Couvade syndrome in expectant fathers. Journal of reproductive and infant psychology. 2007;25(1):18-39.

13. Trethowan WH. The couvade syndrome-some further observations. Journal of psychosomatic research. 1968;12(1):107-15.

14. Mason CE, R. Is there a physiological basis for the couvade and onset of paternal care? International journal of nursing studies. 1995;32(2):137-48.

15. Riggs E, Yelland J, Szwarc J, Wahidi S, Casey S, Chesters D, et al. Fatherhood in a new country: a qualitative study exploring the experiences of Afghan men and implications for health services. Birth. 2016;43(1):86-92.

16. Lina Mrayan R, MSN, PhD1, Sanaa Abujilban, RN, RM, MSN, PhD1, Jamila Abuidhail, RN, MSN, PhD1, Muneer Bani Yassein2, and Hanan Al-Modallal. Couvade Syndrome Among Jordanian Expectant Fathers. American Journal of Men's Health 2019;13(1):1-9.

17. Zarabi H KSArcoCs. A rare case of Couvade syndrome. Research in Medicine. 2001;25(3):199202. 